\title{
Exploring the Cultural Differences Between the US and China in "The Joy Luck Club" Through the Lens of Family Values
}

\author{
Xue Tang ${ }^{1, *}$ \\ ${ }^{I}$ School of Literature and Arts, Southwest University of Science and Technology, Mianyang, Sichuan, China \\ *Xue Tang.Email:1730016972@qq.com
}

\begin{abstract}
The article aims to explore the differences in Chinese and American family values between the two generations of immigrants in the film "The Joy Luck Club". Mainly through literature research method, case study method, exploratory research method and qualitative research method, it finds that the cultural differences between the Chinese and American family values in "The Joy Luck Club" are large. It also combines Hofstede's cultural dimension theory to find out the reasons for the cultural differences between the two. The article is to provide a reference for effectively reducing or avoiding cultural conflicts in intercultural communication in the future.
\end{abstract}

Keywords: "The Joy Luck Club", family values, cultural differences

\section{INTRODUCTION}

Chinese mothers and their daughters living in the United States, who grew up in different cultural backgrounds, represent traditional Chinese culture and American culture respectively. The word "Xi Fu Hui" is the name of the weekly mahjong gathering of the four mothers in the United States, and the film shows us the vast differences and conflicts in family values between the Chinese and American cultures. Throughout the work, family values include not only the conflict between mother and daughter, but also the conflict between husband and wife. This work reflects the typical Chinese and American family values, which helps us to explore these differences and conflicts easily, thus helping us to correctly grasp different family views in cross-cultural communication.

\section{THE \\ MANIFESTATION \\ OF DIFFERENCES IN FAMILY VALUES BETWEEN CHINA AND THE UNITED STATES}

\subsection{Differences in Family Education}

The film shows the difference between Chinese and American family education views incisively and vividly. Suyuan $\mathrm{Wu}$, who has experienced the suffering of war in
China, went to the United States to pursue a better life, but everything did not go well. Therefore, she pinned all her hopes on her daughter, Jingmei $\mathrm{Wu}$, and let her learn all kinds of knowledge and skills. What she expected was an obedient daughter. However, her daughter, who was influenced by American culture since she was young, was very dissatisfied with this, thinking that her freedom was restricted. The mother thought it was just her wish for her daughter. "As a mother, you can never give up your expectations of your children." But when the hope is not fulfilled, then the hope will become harmful to the children. Furthermore, in another mother-daughter relationship, her daughter Violet was a chess champion as a young girl. As the mother, Linda was proud of this and boasted about it, and even show off to others. But the daughter was disgusted by this behaviour and rebelled by refusing to play chess.

It has been traditional Chinese culture since ancient times that is "filial piety first" and "respect the old and love the young". In the feudal patriarchal society, parents demanded that their children be obedient and can't tolerate the slightest deviation or rebellion. "All these are closely related to the patriarchal system in conventional Chinese families. There is a very strict hierarchy in the family, and the parents hold the power in the family, and all the family members are obedient to the parents." To some extent, children are the property of their parents. In contrast, parents have high expectations of their children, 
and the concept of "expecting their sons to become dragons" and "expecting their daughters to become phoenixes" is deeply rooted. So, from this point of view, the mother Suyuan Wu's expectations of the child are beyond reproach. And Linda Gong's show-off of her daughter's chess skills is a face concept at the work. This is unacceptable in the eyes of Westerners. In their culture, which advocates independence, individuality and freedom, parents also use "free-range mode" to get along with their children, giving them room to grow on their own. Jingmei $\mathrm{Wu}$ opposed to her mother's arrangement, is in the pursuit of personal freedom and independence. Violet's aversion to her mother's bragging was also because she believed that a person's achievements were a reflection of his or her own ability, not the family, and that her mother had violated her sense of honour. These all reflect the Western cultural thinking of the daughters, and there will inevitably be differences and conflicts with the mothers' traditional Chinese education values.

\subsection{Differences in views of family marriage}

There is also a considerable gap between the Chinese and American views of family marriage. The traditional Chinese concepts also reflected in "The Joy Luck Club", for instance, "arranging a marriage according to the order of parents and the words of matchmakers". In the past, the status of husbands and wives in China is unequal. Women are regarded as men's accessories. They must respect their husbands. Women can only live for others and are not allowed to have their own needs. Westerners, on the other hand, believe that each person has the right to pursue happiness. Each of us is an independent being, and that the status of husband and wife is equal. For example, Linda Gong was promised to the Huang family when she was 4 years old, and she married at the age of 15 and became a child bride (a little girl raised in the family of her future husband). Faced with marriage, she had no choice. After her marriage, Ruth gave up her career to become a full-time housewife and put her husband at the centre of everything. Ted was so tired of it that he thought she was no longer the independent Ruth with her own ideas. At this time, Ruth is a typical "Chinese-style wife" (It also means a wife with traditional Chinese characteristics.), based on her husband's mood. But Ted thought that the independent and autonomous Ruth is what he likes. And it is the expression of the western idea of equal status of husband and wife.

\subsection{Differences in personal values}

"Value is the deepest part of the culture, which dominates people's beliefs, attitudes and actions."It can be seen that values have a certain degree of relative stability in a period and cannot be easily changed. The personal values of China and the United States also show differences in "The Joy Luck Club". At that time in China, children were their own value. This is a personal value that mothers uphold. For example, among all the wives and concubines of Qing $\mathrm{Wu}$, the status of the second concubine is considered to be the most precious. Just because she has a son, even though the son was snatched from the fourth concubine. In the West, on the other hand, the value of the individual is clearly separated from that of others. "Personal quality and dedication are the key factors to success, while personal family background or other social relations do not necessarily play a decisive role. " Linda Gong flaunts her daughter's chess talents as a source of pride, while her daughter abhors this behaviour and feels that her mother is violating her rights because it is her personal success that she has achieved. It reflects the individual tendency of western culture.

\section{THE REASONS FOR THE DIFFERENCES IN FAMILY VALUES BETWEEN CHINA AND AMERICA}

This paper intends to discuss the reasons for the differences between Chinese and American family values in "The Joy Luck Club" from the cultural dimension of Hofstede. In the book "Cultural Constraints of Management Theory" published in 1993, Hofstede gave the corresponding indexes of the first five dimensions of some countries and regions. Among them, the higher the index, the higher the relative degree of the value of culture and society. As can be seen from the table, the indexes of power distance, long-term and short-term orientation, and personal orientation are significantly different between China and the United States. Therefore, the article will discuss from these three perspectives.

Table 1. The Corresponding indices of five dimensions in some countries and regions

\begin{tabular}{|c|c|c|c|c|c|}
\hline country & $\begin{array}{c}\text { personal } \\
\text { orientation }\end{array}$ & $\begin{array}{c}\text { power } \\
\text { distance }\end{array}$ & $\begin{array}{c}\text { long-term } \\
\text { /short-term } \\
\text { orientation }\end{array}$ & $\begin{array}{c}\text { masculinity/f } \\
\text { emininity }\end{array}$ & $\begin{array}{c}\text { uncertainty } \\
\text { avoidance }\end{array}$ \\
\hline USA & 91 & 40 & 29 & 62 & 46 \\
\hline Netherlands & 80 & 38 & 44 & 14 & 53 \\
\hline France & 71 & 68 & 30 & 43 & 86 \\
\hline Germany & 67 & 25 & 31 & 66 & 65 \\
\hline Russia & 50 & 95 & 10 & 40 & 90 \\
\hline Japan & 46 & 54 & 80 & 95 & 92 \\
\hline
\end{tabular}




\begin{tabular}{|c|c|c|c|c|c|}
\hline China & 20 & 80 & 118 & 50 & 60 \\
\hline West Africa & 20 & 77 & 16 & 46 & 54 \\
\hline Indonesia & 14 & 78 & 25 & 46 & 48 \\
\hline
\end{tabular}

\subsection{Power distance}

"Power Distance refers to the acceptance of the unequal distribution of power in a society or organization by a low-status person in a certain society." That is the attitude and acceptance of social hierarchy. The high power distance culture has a high degree of acceptance of social hierarchy and even thinks this is a natural thing. It emphasizes management and obedience, and often presents a "pyramid" structure. However, the low power distance culture has a low degree of acceptance or even rejection. It emphasizes teamwork and presents a "flat structure". The corresponding indices in the table show that China tends to be a high power distance culture, while the USA is a representative of a low power distance culture.

At that time, China paid more attention to seniority, status, authority, etc. And there was a strict concept of family hierarchy, which was mainly reflected in respecting parents and subordinating women to men.

In "The Joy Luck Club", Suyuan Wu believes that "There are only two kinds of daughters: those who obey the adults and those who don't. Only obedient daughters can live in this home." This reflects the hierarchical concept of "respecting parents" in Chinese traditional culture. When Ted heard his mother say some racist and insulting remarks to Ruth, he turned on his mother. This is simply unforgivable and immoral in Chinese culture. Ruth took her husband as the centre of everything after her marriage, which also reflected the "husband is respected" in China at that time. In contrast, the West advocates equality between husband and wife. In terms of the relationship between parents and children, the two are more like friends.

\subsection{Long-term and short-term orientation}

This dimension can also be referred to as the "Confucian Spiritual Motivation" and is related to Confucian cultivation. From this perspective, many scholars advocate that long-term orientation can bring long-term returns. Long-term orientation means that people pay more attention to long-term developmentoriented returns. For example, Chinese culture has this orientation. While the short-term orientation focuses on short-term returns, as in American culture. In "The Joy Luck Club", Jingmei Wu's mother pinned her hopes on her daughter, letting her learn a lot of knowledge and skills since she was a child, for future development. This is the long-term return that Chinese culture prefers. It is difficult for the daughters who are deeply influenced by American culture to understand.

\subsection{Collectivism and Individualism}

The higher the index of individualism, the more individualistic the society within the culture. The lower, the more collectivist. That is the closeness of the relationship between the individual and the collective. In China, there is a close relationship between the individual and the collective, and collectivism is higher than individualism and more inclined to collectivism. Chinese families belong to the extended family, including not only parents, children, but also the existence of "four generations under one roof". The complex network format family structure constitutes an "inner group". Especially in the pursuit of harmony among the internal groups, China is more obvious. For example, in the Chinese culture, "respect others and humble oneself", which is an attitude of modesty in order not to reveal oneself, so as to get along well with the people in the group, reflecting the word "harmony". Chinese people adhere to the concept of "Conceit leads to losses while modesty brings benefits." In China, for example, there are many self-depreciatory expressions used to address people in an inner group when introducing to others, such as "Jia Fu" referring to "my father". There are also a lot of honorific words for addressing others, such as "Ling Zun" referring to "your father". "Under the guidance and influence of 'man-nature harmony' in China, ideology, thinking mode and speech view tend to seek the whole, general, comprehensive and perceptual intuition." Therefore, most Chinese believe that "Man proposes, God disposes", willing to be "the willing ox to serve the children" (It means willing to serve the people around you.) And they tend to repress their emotions.

On the other hand, the American family belongs to the nuclear family type, which pays more attention to individual uniqueness, innovation and freedom. They believe that after individual interests are satisfied, the collective interests will naturally be satisfied, which is a typical tendency of individualism. So, they suppress their feelings relatively less time, more advocate the courage to express their own feelings and needs.

For example, in "The Joy Luck Club", On the day of her mother's suicide, Anmei Xu learned to scream. This is not just a scream, but also her brave expression and resistance after breaking through the tolerance and suppression in the traditional Chinese family view. When Violet learned that her mother used her as the capital to 
show off, she was extremely disgusted and felt that her rights and interests had been violated. This is a typical manifestation of individual independence in American culture. In the traditional Chinese culture, children, as one of the family members, are responsible for the whole family. That is, family interests come first. Therefore, from the perspective of Chinese family value, Violet's rights and interests have not been violated. Another example is that after Anmei Xu's mother was forced to remarry, her whole family felt ashamed and drove her out of the house. In this way, in the collectivist culture, the importance of the supremacy of collective interests can be seen.

\section{ENLIGHTENMENT: \\ FROM CULTURAL CONFLICT TO CULTURAL FUSION}

There are differences in family values between China and the United States so that there is different degree of cultural conflicts between these two generations. In "The Joy Luck Club", the four mothers of the first-generation immigrants represent traditional Chinese culture, while the daughters of the second-generation immigrants represent American culture. At the end of the film, the gradual reconciliation between the two generations also represents the cultural integration of different family values in China and the United States. This is a model of the integration of Chinese and Western cultures. In most cases, intercultural communication has a process of "cultural difference - cultural conflict - cultural integration". The reasons for the differences in family values between the two are closely related to many factors of power including power distance, long-term and short-term orientation, collectivism and individualism. Therefore, it also suggests that in the process of intercultural communication, we are supposed to understand each other's cultural background in advance, respect each other and deal with it with an open and inclusive attitude. From this, as to reduce or even avoid cultural conflicts and achieve cultural integration.

Besides, I'd like to take some supplements. First of all, we ought to realize that "Cultural conflict is a natural symptom in the process of intercultural adaptation." Secondly, cultural integration mentioned here does not mean assimilation, but a kind of "seeking common ground while accepting the existing differences". In other words, as a scholar, Xiaotong Fei put it, "Each form of beauty has its uniqueness. Precious and valuable is to appreciate other forms of beauty with opening-up. If beauty represents itself with integrity and variety. The world will be blessed with solidarity and harmony." After all, "no single culture can exist. There are communication and integration among all cultures in the world." Thirdly, both Chinese culture and American culture in this paper are set in the 20th century, that is, the era reflected in "The Joy Luck Club". And every culture should not be limited to a qualitative framework but will evolve and develop with social changes, and it is dynamic. There will be mutual integration between different cultures, so we should understand it from the perspective of development. Finally, in the process of intercultural communication, we should jump out of the cultural stereotype and concrete analysis of concrete conditions. While learning the mainstream culture of the others, we are also supposed to understand the existence of its subculture. When understanding cultural similarity, we also do not forget the existence of cultural individuality.

\section{CONCLUSION}

In recent years, with the in-depth development of globalization and the proposal of "human community", the cross-cultural phenomenon has become more and more normal. Cultural differences have also brought some difficulties because of the different factors such as cultural background, social system and mode of thinking. From the perspective of family value, this paper explores the cultural differences and their causes between Chinese and American culture in the film "The Joy Luck Club". The first part analyses the differences between Chinese and American family values: the differences in family education, family marriage and personal values. The second part explores the reasons for the differences between the two kinds of family values: Based on the cultural dimension of Hofstede, it can be understood that it has a great relationship with power distance, long-term and short-term orientation, collectivism and individualism. The third part proposes the attitude and behaviour we should hold in the process of cultural conflict to cultural fusion. By comparing the differences in family values between China and America, this article aims to find out the reasons for the differences, and provide a feasible reference for future intercultural communication.

\section{AUTHORS' CONTRIBUTIONS}

This article is written by the author independently. Taking the film "Joy Luck Club" as an example, this paper compares the differences between Chinese and American culture in family values. And based on Hofstede's cultural dimension theory, the reasons are analysed. This angle is relatively novel. It aims to provide a reference for future intercultural communication.

\section{ACKNOWLEDGMENTS}

This article quoted some sentences from other scholars' articles as references. Listed in the reference section, and thanks.

\section{REFERENCES}

[1] $\mathrm{Hu}$ W. (1999) Interpersonal relationship. In: Wenzhong Hu.(Eds.), Introduction to Intercultural 
Communication. Foreign Language Teaching and Research Press, Beijing. pp. 140.

[2] $\mathrm{Hu}$ W. (1999) Values. In: Wenzhong Hu.(Eds.), Introduction to Intercultural Communication. Foreign Language Teaching and Research Press, Beijing. pp. 175.

[3] Pan W., Chen J., Zhong H., (2008) Foreign Culture and Intercultural Communication. Huazhong University of Science and Technology Press, Wuhan.

[4] Guo J. (2015) On the embodiment of Hofstede's cultural dimension theory in "the novel Joy Luck Club". Appreciation of masterpieces, 35: 93-95.

[5] Li W. (2009) Hofstede Cultural Dimensions and Intercultural Studies. Social Sciences, 12: 126-129+ 185.

[6] Jia Y. (1997) Intercultural Communication. Shanghai Foreign Language Education Press, Shanghai.

[7] Pan W., Chen J., Zhong H., (2008) Foreign Culture and Intercultural Communication. Huazhong University of Science and Technology Press, Wuhan.

[8] Lu Z. (2010) From "harmonious but different" to "symbiosis of the beautiful". In: Proceedings of the Sixth (First Overseas) International Symposium of the World Forum on Chinese Culture in the 21st Century. Singapore. pp. 17-21. 